DE DE GRUYTER OPEN
Research Article

(C) 2017 Wirawan ED Radianto and Eko Budi Santoso. This is an open access article licensed under the Creative Commons Attribution-NonCommercial-NoDerivs License (http://creativecommons.org/licenses/by-nc-nd/3.0/).

\title{
Start-Up Business: Process and Challenges in Entrepreneurship Education
}

\author{
Wirawan ED Radianto
}

Eko Budi Santoso

Ciputra University, Surabaya, Indonesia

Doi: 10.1515/mjss-2017-0009

\begin{abstract}
This research aims to explore the process of entrepreneurship education and its challenges based on the facilitators' viewpoints who take parts in the students' business in entrepreneurship education. This case study determines the respondents purposively, and through in-depth interviews by using validated triangulation of methods, the data obtains. The research findings showed the process of entrepreneurship education starts from the process of incubating the students' business. During this process, the research gains several important aspects, for instance, changing student's mindset, bringing up their passion, and formulating target, performance indicators, and business process. This research also discusses the use of non-financial indicator as the indicator mostly used the faciltators to measure the students' business performance. Furthermore, this research reveals that the facilitators should provide stimuli, give gradual assistance and guidance, and know the business needs of the students. Finally, the challenges identified are the difficulties to change mindset, the distinctiveness of each student's business, the resources required by the facilitators, and facilitation and time management skills.
\end{abstract}

Keywords: education, entrepreneurship, start-ups business, challenges

\section{Introduction}

The high rate of unemployment and the slow pace of economic growth have always become economic challenges faced by developing countries, including Indonesia. One of the aspects that affect the economic progress of a country is the poverty rate. The government of Indonesia has tried to overcome these challenges, which one of the efforst is to reduce unemployment by increasing the number of entrepreneurs.

Currently entrepreneurship has become the focus in developing countries including Indonesia. Since 2011, the government has tried to increase the number of entrepreneurs by launching entrepreneurial movement in order to increase the number of entrepreneurs in Indonesia (Aprilianty, 2012). The ministries in Indonesia, namely the Ministry of Cooperative and SMEs, the Ministry of Trade, the Ministry of Manpower and Transmigration, and the Ministry of Research, Technology and Higher Education, respond this movement by implementing their own specific programs to increase entrepreneurship. In addition to that, the local government and the city government also have their special entrepreneurship program.

The Ministry of Research, Technology and Higher Education has launched the Student Creativity Program (PKM) to stimulate entrepreneurs from campus. To respond this program, the universities in Indonesia establish their entrepreneurship development program. Fortunately, the society also begin to show their response towards the program. The increased numbers of 
unemployment, difficulties in finding proper job, and emergence of new young entrepreneurs have made the society understand the significance of teaching entrepreneurship early at school.

However, the purpose of entrepreneurship education is actually similar with its entrepreneurship implementation, while the strategies of entrepreneurship education program vary between educational institutions. Almost all higher education institutions have entrepreneurship education programs yet is limited to the knowledge level only (to know). In other words, entrepreneurship education is only viewed as branch of knowledge and not as a branch of practice. Therefore, it is not surprising that in most undergraduate programs in Indonesia, entrepreneurial program of undergraduate level (S1) only has three out of about 144 credits. To be honest, how can an entrepreneur program with very few credits inspire the students to become entrepreneurs?

This research aims to explore the process of entrepreneurship education and the challenges faced. Due to this reason, the research setting that is able to facilitate this research in reaching its aim is universities that perform entrepreneurship education. Ciputra University (UC) is the first university in Indonesia with vision to produce entrepreneurs. With its grand vision, the UC implements entrepreneurship education through active educational methods, such as experientialbased learning. The UC entrepreneurship education program does not only provide knowledge about entrepreneurship but also provides education with entrepreneurial ways (to be). This program gives opportunities for the students to experience real business as the UC the students, where the implementation of active learning-based teaching method requires the students to involve themselves in real business life to make them have business experience. In this program, the students are required to have their own business, to feel the joys and sorrows of how to run business, with expectation that they are able to overcome obstacles and challenges in their business later in the future. This process of pioneering business has started since the students are in their first year, and has become the requirement for their bachelor degree from the UC.

Every lecturers of the UC must become a facilitator of the students' business in order to support the success of this program. Therefore, the UC provides entrepreneurship trainings to ensure that the lecturers (as facilitator) be able to guide their students' project. Besides that, UC also recruits entrepreneurs to teach at the UC. Most entrepreneurs and professionals respond this program positively and they agree to join the program.

One of the keys to successful entrepreneurship education is the competence of the facilitators that will guide the students' business, starting from finding ideas, initiating and stabilizing the business, to continuing the business in real life when the student graduate later. Therefore, the facilitators play very important roles in guiding the students, such as becoming their mentor, discussion collaborator, and parent to encourage and give advice for the students to run their business.

This research attempts to explore the process of entrepreneurship education and challenges faced in implementing this program. This research uses the facilitators' viewpoints of the program implementation in entrepreneurship education. The originality of this research bases on two aspects, where the first aspect is by considering the viewpoints of the facilitators as research subjects, and the second aspect is by describing the experiential-based learning method implemented in entrepreneurial university. This research contributes as reference of entrepreneur literature on business pioneer process in entrepreneurship education. Additionally, this research can also be a reference for other educational institutions who have vision to produce entrepreneurs. The research expectation is useful for entrepreneurship program managers in order to increase the numbers of graduates who later become entrepreneurs.

\section{Literary Research}

Entrepreneurship is a process to create something different in order to achieve the prosperity of individuals or groups through the creation of value added (Winarto, 2004; Alma, 2014; Fakhruddin, 2012). The Presidential Decree 4 year 1995 declares that entrepreneurship is a someone's passion, attitude, behavior and ability to handle business or activity directed to seek, create, and implement methods of working, new technologies and products to improve efficiency in order to 
provide better services and or obtain larger profit. Regarding this, entrepreneur is someone who creates something new for people's benefit. According to the researchers themselves, entrepreneurial is someone who maximizes and processes his or her own resources to have value added and to compete, in order to seek new opportunities and measure the risk on these opportunities and then take advantage of that opportunity to create a better economic life.

\subsection{Entrepreneurship Education}

Entrepreneurship process is the process of creating value and can be done by either a new entrepreneur or an experienced one (Stokvik et al., 2016; Buchari, 2007; Hakim, 2012; Mahfud, 2012). Besides entrepreneur term, there is also intrapreneur, which is a term addressing someone who has entrepreneurial character, spirit, and put him or her into practice in the other's company (Nicholson et al., 2016). There are four categories of entrepreneurship, namely business entrepreneur, academic entrepreneurs, government entrepreneur and social entrepreneur (Ciputra, 2007). Business entrepreneur is a creator of business as well as the business owner. Academic entrepreneur refers to those who become educators, researchers and managers of educational institutions with entrepreneur pattern and style while always maintain educational purposes. Government entrepreneur refers to those who lead and manage government institutions or public sector institutions with entrepreneurial spirit, and social entrepreneur refers to those who manage social or non-profit organization to collect funds from public for social purposes.

Entrepreneurship can emerge from three things: nature, nurture, and training. Nature refers to the condition when someone was born to entrepreneur parents and is likely to follow his or her parents' example, even becomes the successor of family business. Nurture refers to the condition where someone, although was not born to entrepreneur parents yet raised in entrepreneur environment, will more likely to be entrepreneur too. What if someone was not born to entrepreneur parents and grew up in entrepreneur environment, can someone become an entrepreneur? The answer depends on the amount of entrepreneurship trainings and education. In the researchers' opinion, with the right system, curriculum, and teachers, everyone can be educated to become entrepreneurs.

Several empirical researches prove that entrepreneurship is teachable (Douglas \& Shepherd, 2002; Pihie \& Sani, 2009; Glass \& Freeman, 2016; Wahid et al., 2017; Siswoyo, 2009), since the findings show that after receiving lessons on entrepreneurship, the students' knowledge improve. Moreover, entrepreneurship education makes the students understand the risks of opening new business, while at the same time it gives them courage to open their own business. Lestari and Trisnady (2012) find that entrepreneurship education stimulates interest of entrepreneurship, which ultimately will have effect on the emergence of young entrepreneurs with vision, creative, and innovative in their field of expertise. Due to this reason, entrepreneurship education must implement a well-established planning and effective learning method and activities, and use appropriate approaches that are suitable with the culture of the school or educational institution where entrepreneurship education is taught. Nurseto (2010) adds that entrepreneurship education is a different concept of education, aims to produce creative and innovative the students. This pattern of education requires the students to be productive. Entrepreneurship education aims to direct the students to and equip them with entrepreneurial character, thus enabling them to respond quickly to changes and to understand the needs of socio-economic communities (see opportunities). In addition to that, Sarwoko (2011) finds that the higher the support to the students, the higher their self-confidence and mental maturity will be, as well as their entrepreneurial intention.

This research explores how entrepreneurship education through experiential-based learning as a living and real laboratory facilitates the students within the learning process, since every student must establish a real business. Through a real business experience, the students are expected to be completely ready as a real entrepreneur. Experiental-based learning method can improve the students' self-confidence, managerial ability, decision-making ability, and interpersonal skills that are needed to become an entrepreneur (Skinner et.al. 2016; Lee, 2016). Which is why, entrepreneurship education needs concrete activities (hands-on) by involving all the students in real business activities. Through this entrepreneurship process, the students can develop their 
entrepreneurial competencies to cope with challenges that may arise. They will also have real hard skills and soft skills since they actually experience real business life, as well as entrepreneurship knowledge, entrepreneurial character, self-discipline, independence, and other required skills. Furthermore, Priyanto (2009) and El-Gohary et.al. (2016) state that the basic principle of entrepreneurship is to make the students interested and motivated, and be able to see profitable opportunities.

The entrepreneurship education has different output indicators with other education programs, where most of them focus on the cognitive aspects or hard skill. In contrast to entrepreneurship education which has very wide dimensions and different effects to its outputs, a conservative education aims to produce graduates who are ready to be trained to work (usually their graduates are not ready to work), while entrepreneurship education aims to produce entrepreneurs who are able to create jobs. Theferofe, entrepreneurship education is what Indonesia needs right now in order to cope with high unemployment rates.

\section{Research Method}

This research is qualitative in nature, which aims at exploring the process of entrerepreneurship education. The Ciputra University is the research site since this university is the first university in Indonesia that provides entrepreneurship education. The research design was descriptive approach. Thus, a case research design becomes as the research design to enable the researchers in doing in-depth exploration on how entrepreneurship education process implemented at the UC, in order to obtain deeper information and to describe the process by focusing on specific subjects (Yin, 2003).

The respondents for this research are the lecturers of the UC who are also the facilitators for the students' business projects. The facilitators selected as the respondents are those who succeed in leading the students to do their business, as marked by the awards of recognition for their achievements in entrepreneurship education. All the informants have become the facilitators for more than three years, or have become mentors for six semesters. They also have participated in entrepreneurship training, and some of them have ever become the coordinator of entrepreneurship program at the UC. To ensure the data validity, the researchers use triangulation of methods consist of interview, documentation, focus group discussion, and observation, where the documentation and field observation are used to confirm the data obtained from in-depth interviews and focus group discussion.

\section{Analysis and Discussion}

As the first university in Indonesia that provides entrepreneurship education, the UC applies different learning methods from the other universities in Indonesia. The objective of education in the UC is not only to make the students know about entrereneurship (to know) but to make them become an entrepreneur (to be). At the UC, the students are taught in such a way to become entrepreneurs; therefore, one of the effective ways is by implementing student-centered dlearning. This section discusses the process of entrepreneurship education at the UC, the process of initiating the students' business project, and the ways the facilitators guide the students in their business project initiation. Some of the findings discussed in this section are changing the mindset and formulating targets and performance indicators, and guiding the students. Furthermore, this section also discusses how the facilitaters cope with the challenges encountered during the process of guiding the students.

\subsection{Entrepreneurship Education at the UC}

As the first university to initiate entrepreneurship education in Indonesia, it is a policy of the UC to offer entrepreneurship classes in each semester starting from the first semester to the seventh semester. The entrepreneurship education held at the UC is divided into two programs: the entrepreneurship program at the department level and at the university level. The entrepreneurship 
program at the department level is managed entirely by each department in the UC, starting from its planning, implementation, to evaluation, while the entrepreneurship program at the university level is managed in intra-departmental way. All the students of the UC must enroll in the university-level entrepreneurship level, where the lecturer and the business practitioner teach them. These programs support and complement each other in order to provide comprehensive education for the UC the students.

As a case study research, this research focuses on the entrepreneurship program run by the School of Business and Management as the largest faculty of the UC. This faculty offers entrepreneurship program with more credits than other faculties have, where more than $30 \%$ of the course credit in the faculties are entrepreneurship courses. The teaching method applied in this faculty is experiential-based learning, where the students are required to initiate a real business project in each semester. Their business project will become the basis for creating their final report. The goal of this program is to make the students experience learning together with the life cycle of a sustainable company, to make them able to demonstrate entrepreneurial attitude and character, and to make them create business where after completing their study they can continue it.

This education process has different focus in each semester yet is respectively interconnected between semesters, ensuring the students to continue running their business. The following descriptions are stages of the entrepreneurship program.

Semester 1- Ground breaking. In this early stage, all the students learn to organize an event by holding a big event. For this event, they must bring many visitors and publicize the event using media such as newspapers, television, and radio, and be challenged to earn profit. The purpose of this project is to inspire the students about how entrepreneur works and to facilitate them in experiencing certain entrepreneur characteristics such as creative, innovative, entrepreneur, measure occurred risks, behave ethically, persistent and do not give up easily.

Semester 2- Ideation and Market Testing. Next, in the following semester, the students are asked to create a group of businesses consists of five the students. They must design a business plan and conduct market testing to test the product they create. They have to make sure that the product or service they produce can be accepted by the market. In this process, the students learn to have market sensitivity, increase creativity and innovation, be persistent, and demonstrate presentation and negotiation skills.

Semester 3- Business Start-Up. In this third stage, the students begin to form their business based on the business plan they create previously. Each business project found must give certain target, for example, to reach certain income. Pioneering a real business starts in this semester, where the students experience real business on starting and running a business with limited assets which are provided by their group members.

Semester 4- Benchmarking. In the fourth semester, the students continue to run their business, which is initiated in the third semester. Different targets are set, such as publicizing their business in mass media, participating in certain exhibitions, and many more. At the same time, they are required to look for a sister company for benchmarking purpose. In this semester, the students can gain more knowledge, insight, and business tricks on the marketing, accounting and finance, human resources, and other operational things. This benchmarking activity is to inspire the students by engaging them in real business activities with the other successful business practicioners from well-established companies.

Semester 5- Expansion through innovation. In this semester, the students keep running their business, but they must have increased targets. At the same time, they must plan to develop their businesses through innovation. This semester, the students learn to have insights on how to innovate for their business, for instance, doing innovation of product, business model, marketing, and financing.

Semester 6- Sustainability and innovative marketing. In this semester, the students continue their business and have higher target than the previous semester, which is to calculate net profit margin. In addition to that, the students have to execute the expansion plan that they already create in the previous semester. To support their expansion plan, they have opportunity to seek for investors.

Semester 7- Blueprint of business strategy. Semester 7 is the final semester for conducting the students' business. In this semester, the students have the highest target, which is to create a business blueprint for their company strategy in order to run their business for the next three years. 
Through this designed entrepreneurship education, the UC attempts to create educated entrepreneur of Indonesia. This entrepreneurship education program expects to produce entrepreneurs with rich business experience and are well educated in both academic and nonacademic. Through implementing this experiental-based learning, the students can have real business insight to avoid discomfort in business world. One of the most important aspects in entrepreneurship education is the process of initiating the students' business. This process is a tough challenge for the facilitators.

\subsection{The Process of "Incubating Business": Challenge for The facilitators}

The process of incubating the students' business project is one key to the success of entrepreneurship education in order to produce educated entrepreneur. This research explores the process of how the facilitators guide their students to initiate their business.

The entrepreneurship education at the UC has started since the first year of the students' study time, where they are required to experience entrepreneurship education by holding a largescale event. Furthermore, in the next semesters, each student must form a group to initiate their business project. Before entering the next semester, they have to present their business plan in front of their lecturer who plays a role of a facilitator. Later, the business plan must be actualized in the next semester.

The most important aspect in starting the students' business project the students is to change their mindset. The change in the students' mindset is also an indicator of success for the students' business projects. In each semester, the program uses various media, methods and programs to inspire the students and to create their entrepreneurial spirit and mindset. One of the programs of UC is to invite entrepreneurs of various fields of expertise to give public lectures, seminars, and to become guest lecturers in classes. This inspiration process can gradually affect the students' mindset, where is indicated by the students' passion in initiating their own business.

\section{3 "Passion Does Not Always Grow Automatically"}

One of the challenges that the lecturers face with in starting entrepreneurship education is how to foster the passion among the students. Actually, in this entrepreneurship education, it takes all efforts at the beginning of college time to foster and grow the entrepreneurship passion as expected. At the UC, the facilitators foster entrepreneurship passion of the students by digging their interests, and later by asking them to do experiment on what has become their interest. For example, when the students have passion to make bread, the facilitator will ask them to do experiment with baking in order to make sure that they really have passion for making bread. The facilitators must understand the importance of passion since it is the foundation for the students to manage their business project well as required. This act of seriousness is one of the students' assets to succeed in their business projects.

The next way is to use the effectuation concept. With this concept, the facilitators together with the students (through a long discussion process) can identify what are the students' strengths, advantages, and hobbies. For instance, if a student has strength in designing clothing, the facilitator will lead his or her to fashion business.

On the other hand, the lecturers also need to foster the passion for entrepreneurship. So how is it different with fostering the passion for the students? Evidently, empirical studies show that the lecturers' passion has to foster and grow to enable them guide the students who have different business project with the lecturers' own business passion. A facilitator with a passion for food and beverage, for example, must be willing to guide the students who are not interested in food and beverage business, as explained by one of the informants below,

"To be honest, I do not have passion in that kind of business, yet it does not mean that I cannot coach the students, and apparently there are some additional factors that make him (the student) could not work his best. Therefore, the real key to success is... I can say that it depends on how deep we want to coach them" 
After fostering and growing the students' passion to start business in their chosen fields, the facilitators then must formulate targets for the students to achieve, in order to ensure that they will immediately start their the business.

One of the facilitators' efforts to grow the students' passion is by asking them the students to use the effectuation strategy, to make sure that the students are not confused when choosing their business project. Through this strategy, the students will conduct business based on the expertise and passion that they have, by asking them to identify their strengths in maximizing their business idea.

The facilitators' expectation when implementing this strategy is to motivate the students to work hard for their chosen business since it is a business that suits their current condition. This strategy is successful since the facilitators' advisees have succeeded in initiating their business and received award in the semester where they are running their business.

\section{4 "Target": a Motivation Tool}

The next stage done by the facilitators to make sure that the students run their own business is motivating the students. The facilitators motivate the students by formulating their targets, to make them focused more when running their business and to direct resources. To achieve that, the target must be set together with the students. The students are more motivated when the target are discussed together, while on the contrary, they become less motivated if the target is set by the facilitators only.

Formulating the target is not easy. Most the students do not have a proper basis for formulating target type and size. When being started, almost all of the students' business projects only set the revenue or profit as target type, yet the students have no idea when they are asked about determining the revenue or profit size, some are too big or too small (in the facilitators' opinion). This means that the facilitators should guide the students to set these targets. They have to guide the students slowly in order to keep them motivated. This process is challenging enough for the facilitators, since each of them surely has personal target size, such as focusing on the financial target, non-financial target, or on both targets. To overcome this challenge, the research program sets its policy to assign a senior lecturer as a coordinator of the students' business project with purpose to unify the targets. Though the problem of different targets can be resolved by setting the target standard, to implement this in the real practice is still difficult, due to the facilitators' own consideration and different business groups' performance. One facilitator can feel that a certain target benefits specific business group and harms other business groups, or the other way around. Thefore, discussions and setting policies on the targets that are suitable with the students' business project type are chosen to resolve this problem. As for the impact, each business project will have several targets that later be accumulated. This solution can also be used to overcome differences occurred among the students, since some of the students can have different opinions about their target. There are the students who believe that revenue is the most appropriate target since it symbolizes their business performance, and there are the students who agree that production capacity can be used as target. By taking this as a consideration, the facilitators should steadily lead the students to formulate their targets.

These research findings also expore the financial targets and non-financial targets. The financial targets include sales revenue and profit, while the non-financial targets include relationships, distribution channels, publications, and other aspects beyond financial aspects. The real conditions suggest that the target formulation process is usually based on the rules set by the research programs through their coordinator, and later are developed by the facilitators. That way, each of the business projects will share several similar targets, while the rests of the targets depend on the agreement between the students' group and their business facilitator. Target setting is critical to the success of the students' business projects. All the facilitators, based on their experiences, agree that a business project without target will not last long, even when that business has survived for a long time it can be said as does not have business performance since it only runs blindly. Regarding this target setting, this research found out that almost no the facilitators make financial targets as their main targets but non-financial targets. 
Furthermore, after agreeing on the target form, the process continues by discussing how big the target to achieve is. This process is usually more difficult and longer than the target setting process. More often, the students have to argue with their facilitators when they think the facilitators set the target too big. When this process is re-checked, the facilitators argue that they see their students have great potential yet the students refuse to be assigned with big target or target size that is suitable with their potential.

One of the reasons why the facilitators set non-financial aspects as the target is due to their experience that if the students are asked profit as target, it is possible for them to do negative things such as manipulating the profit and many more. That is why, in this process, the facilitators set non-financial targets first such as the certain number of customers, the implementation process, and many more. This is also due to the students' business stage that is still in the stage of start-up business or in the process of entering the market. During this stage, the facilitators gradually guide the students by giving increased targets, in order to monitor their business growth. According to the facilitators, this way can help the students. Evidently, when they are given a big target at the beginning of their project, they can lose their business motivation, while on the contrary, when they are given a small target to achieve, they will lose focus on their business or even do not work on their business project at all. Therefore, it is very important to do this target setting stage properly.

Having inspired the students to rise their passion and set their target, as one of the efforts of controlling the students' business project the facilitators are now guiding the students to set their business project performance indicators.

\subsection{The students' Business Performance Indicator: a Tool to Control Start-up Business}

Performance indicators are very important to see to what extent is the business achievement of the students. Utomo (2010) states that one of the characteristics of the entrepreneur is to focus on performance, so the performance indicators are crucial as a tool to control the entrepreneurship education process. During interview process, when the researchers investigate the facilitators on what are indicators of the students' success, they surprisingly never mention that financial indicator is a main indicator of success. From the interview result, they claim that they never apply financial indicators since there are some business groups that cannot calculate their financial aspect accurately. As said by one informant,

"If we calculate our profit only from the raw material then it is wrong, Sir, not to mention the energy, time and gas they have spent, if they calculate all those aspects, they actually loss in their project".

One of the weaknesses of the students' business group in calculating their profit is that almost no business groups calculate their labor cost, including gas and other utilities (electricity, water) and stationeries. This actually makes bias on their income statement.

Performance measurement, according to the facilitators, does not give a real picture of the students' business performance since good results are not necessarily done through a good process anyway. Therefore, the facilitators tend to focus on the process being run rather than results achieved by the students' business projects. The good financial achievement that is described in a high amount of income and profit actually means nothing if the students carry out the process in a wrong way. In other words, actually, the facilitators want to say that the students can easily manipulate that financial indicator. Besides, if the students carry out the process in the right way, it will automatically affect the financial aspect of their business project.

\subsection{Financial Indicator: "Difficult in Process yet Fast and Easy to Spot"}

One financial indicator used by the facilitators is a sales revenue of the students' business projects. The reason of emphasizing more on the revenue is that they assume that the revenue is easier to see and can become a driving factor for the students' entrepreneurship spirit, which is claimed by one of the informants: 
"Revenue is their driving force, and it is easier to see... and revenue is the easiest target type to see..."

Slightly different from this, one informant claims that he can observe the target market of the students' business group from their turnover. Since the students are just starting their business, the facilitators can calculate the potential of that business idea when being tested in the market by observing their turnover instead of their profit. The facilitators avoid using profit as a tool to calculate the potential of their business idea, because if their profit is as a tool to calculate the potential, then they are considered as experiencing loss due to the stage of their business as a start-up business.

On the contrary, one facilitator argues that "the indicator of a project is to earn profit", which means that profit is another indicator that is important to measure the students' business project performance. He furthermore argues that profit is a one better financial measurement tool since it means the net business benefits earned by the students. Still, the facilitator requires that the right profit come from a right calculation. Hence, calculating the right profit based on the applicable rules has become one of the main challenges to the students' business projects.

\subsection{Non-financial Indicator: "Difficult in Process and Hard to Spot"}

As previously described in the preceding section, almost none of the facilitators emphasize on financial aspects as assessment indicator for the students' success. The facilitators consider that financial aspects are not the main indicator, and there are many non-financial indicators more important than financial indicators. They assume if the non-financial indicators are achieved by the group of the students' business project, then automatically financial indicators will be achieved (this is a usual condition). These research findings also reveal that the facilitators more focused on "the process" rather than the result, which is usually a part of financial aspects of the business. The following description presents the non-financial indicators used by the facilitators as indicators of success.

\subsubsection{Growth}

Some indicators of growth found in the research field are the number of customers, increased production scale, and increased the students' key partner. The number of customers is the first indicator. The facilitators considers with the large number of customers, the students' products or services are actually accepted by the market. When there are customers who show their interest in reordering the product or service, it means that the customers favor the products or services. The larger number of customers indicates that the students' products and services have started to compete with other "old players". The number of customers is a very important indicator since the students' business projects are still in the context of start-up business, and thus almost all of the products and services have differentiation.

The growth of production scale is the next indicator. The facilitators assume the growth of production scale means that the students' business project is able to penetrate the target market although they are still counted as "new player". Indeed, few of them show a very significant growth, but their growth is still visible if being assessed using the criteria established together with the facilitators. The growth can be in form of the number of "key partner in their business, as expressed by one of the facilitators: "how many parties can be asked to cooperate...since relationships can increase turnover and profit".

The following indicator is the students' "key partner" in business, such as customers, suppliers, artisans or their entrepreneur parents. The students must report the suppliers they have, how many are bought from suppliers, how is the quality, how is the payment method, and other matters related to the supplier. Commonly the students report only good things in their report, therefore the facilitators always recheck their report by asking their students' suppliers about the performance of their business. To date, the facilitators' experiences show that the suppliers often give positive information about how the students cooperate with them. The suppliers are also 
pleased when being contacted since they can see this entrepreneurship education process is really controlled by the facilitators themselves. This can calm the suppliers because they feel they can report to the students' facilitators if anything unwanted happens, for example, if there are students who do not pay for their orders. The same thing is also with the customers of the students' business, where the facilitators confirm the students' actions to the customers. Apparently, the customers are more "complicated" than the suppliers are because they often complain about the products being purchased, even though the facilitators think the customers' overdramatize their complains. For example, there are customers who often complain about the students' product yet those customers are the loyal users of the product. The facilitators can monitor this from various sources, including documentation.

Reseller is one important source for the facilitators to make sure of their students' business process. Reseller is the party who entrusts to the products by the students and pays for the products sold. The relationship of reseller with the students must be very close because they have to communicate with each other on daily or weekly dasis, hence the reseller must know about the students' actions in doing business. Resellers will also know the quality of products as well as the customers who purchase the students' project; hence, they also know the quality of the students in doing business. Besides checking by phone, the facilitators often come to the resellers' stores or stand to observe the product and talking to the resellers. They also take picture of the product and compare their own information with the students' report. Other confirmation effort is by checking the students' documents of product distribution to the reseller, including the payment receipt of reseller to the students. This kind of mechanism is apparently strong enough to make sure that the students really working on theirbusiness project.

\subsubsection{The Students' Business Process}

Almost all the facilitators focus on their students' business processes. The process is an important indicator in the start-up business process, since within this process the students can improve their skills in doing business. This process covers raw materials input, processing, and marketing. Each stage is very important to de managed well by the students as the stages provide knowledge and opportunities for them to learn how to run a business. The following is one facilitator's opinion on the importance of understanding of a production process as a business performance indicator.

"... Sales is related to production, and dealing with marketing, because if there is no production, then there is no marketing, no distribution means no selling. So, when the sales is good then the marketing is good therefore the production is definitely good too".

This is also reflected in other facilitator's opinion,

"Even though they have increased financial progress and it can indicate a good performance, we have to recheck whether their increased financial progress is du to the right process."

Often the facilitators require them to avoid selling the products or services to their family or relatives. The students must be able to sell products or services to other people than relatives, family, and even close friends. Similarly, they must get raw or expected materials from people they never know before. For some of the events held, they must look for investors who are not related to them or not their family and relatives. Fortunately, the students' business group can successfully carry out this requirement. They seem to be very happy since having other people (not family or relatives-related) as their investors or trusting them with assets means that they have made it through the process.

Another complicated indicator is "handling customer". The facilitators considers the students' ability to manage complaints from their customers as an indicator of their success in business. This skill shows the students' maturity in negotiating or dealing with other people, especially suppliers and customers. This skill also demonstrates their professionalism. With this skill, the students are expected to be more confident in doing business.

The following indicator is very interesting, which is the existence of problem in the students' 
business group. This is based on the argument that problems can signal a process of the students being mature in business, they have trouble of their own business. Through this experience, the students have stronger business mental and make them more persistent. They learn to create new strategies to avoid the fall of their business, even possible for them to come to their facilitators, discuss the problems and formulate new creative ideas. Regarding this, some the facilitators give certain points to the students who experience problems with their business group. Problems also indicate that their business project is still running and they are still trying to keep their business. Based on one of the researchers' experience, when guiding one business project in the form of a diner, the researcher as facilitator never received a report about the problems experienced by the group, so he thought the business ran well. However, when the researcher inspected, there was never a diner but a place to play game.

The next indicator is behavior change. Change means positive behavioral changes as expected by the facilitators as the UC representatives to make sure that their business run well. Regarding this, observation is an effective control mechanism. The most important change is the change in mindset. The facilitators explain that the main indicator of successful entrepreneurship education is when they manage to change their students' mindset. The facilitators find them easy to lead, direct and motivate when their mindset has changed. The facilitators' years of experience show that the students' business project will have a good performance after they have a changed mindset. They are brave enough to leave their comfort zone hence they have opportunities to move forward.

\subsection{Guiding the Students' Business: a Never Ending Challenge}

After incubating the students' business, the next task is to guide the students in such a way to achieve the set target. This guiding process is very critical since through this process, the facilitators can support the students in order to promote their entrepreneurship intention. Based on their experiences, each stage in this process, such as the stage of initiating business and guiding the business, has its own challenges. The biggest challenge in the stage of initiating the business is to change their mindset, while the challenge in the stage of guiding the students' business project is on how to make this new business improves its performance. Endurance, patience, high skills and knowledge, time, energy, and spirit are very crucial in the process of guiding the students. The students' business project is a real business project, and this is a challenge for the facilitators to succeed as the students give all they have including money for their business. The students have no experience in doing business ever before so the facilitators' role in guiding their business is a key factor to the students' business success as well as to the entrepreneurship education success.

The facilitators clarify their guiding process in systematic process. They do not do it in a hurry; in fact, almost all the facilitators do it gradually. With such pattern, the students' business group come to understand what the facilitators are proposing, such as described in the following opinion from one of the facilitators:

"Indeed, we guide them slowly... to make sure that they really get it, for example, they respond like this: oh yeah Sir I know you mean it this way"

When the facilitators guide the students' business project, they ask them to raise the students' targets in gradual stages. For example, when there is a business group who wants to increase their turnover such as from 20 unit sales to 30 unit sales, they must do it gradually in one or three weeks. During this process, the students can face challenges in increasing their sales performance. To overcome this, the facilitators use other way, which is to motivate them by "making them realize" whether or not what they achieve can meet their needs at that time. For instance, when a the students' business group achieve a certain number of turnover, the group's facilitator will ask them to calculate their monthly needs, and compare their monthly needs calculation with the turnover achieved. If their expense is still larger than the turnover than they will realize that, they do not try harder to achieve the set target. That way, the students are motivated to improve their performance. 
Another challenge faced by the facilitators is that the reality that all the students' business projects share different conditions with each other. Each team has different performance that depends on many things, for instance, different business types have different performances, for example, the performances of food and beverage business and house renovation business. Food business also depends on the models, such as the students who open diner is different from the students who choose consignment model for their business. Hence, each facilitator must guide each specific business as well, since having specific business means having specific needs. Which is why, by providing a specific guidance to the students, the facilitators are actually providing specific assistance for the students' each specific business. These findings are consistent with Sarwoko's research (2011) who claims that the higher the support to the students the higher their self-confidence and mental maturity that ultimately will make their entrepreneurship intentions higher as expected.

Stimulus are very important in the students' business. Interesting things often arise when the students starting a business. For example, some of them do not know what they should do next; however, they do not discuss it with their facilitators. Later, this then becomes a challenge for the facilitators to understand their students' business better. To cope with this situation, the facilitators provide stimulus for the students in form of questions. One of the keys to success in this asking question process is that the facilitators are able to provide "powerful questions", in form of in-depth and accurate questions to make the students realize and focus in running their own business. Generally, the facilitators who are able to provide such powerful questions are those who focus on their students' business processes. By setting their focus on the students' business process, they will deeply understand the problems faced by the students' business group. Instead of helping to solve the problems, they are more likely to provide sharp and detailed questions to the group in order to motivate them to work and improve their business. This method will also enable the students to see their own potential since through answering these sharp questions, the facilitators actually motivate them to come up with their own ideas for their business. This process is similar to coaching strategy where the problem solving ideas usually come from the trainee instead of the coach, as the coach is only trying to help by giving questions to help the trainee think critically and be able to carry out such revisions needed.

One of the challenges that must be overcome by the facilitator is when the students ask for advice yet it is out of the facilitators' area of expertise. Two things the facilitators usually do are to research the questions and seek for the answer, and to seek for assistance from certain experts with the area of expertise that is suitable with the students' questions. Once, a student wanted to have negotiation skills and therefore asked for his facilitator's assistance. Since his facilitator did not master negotiation skills, he sent the student to other negotiation expert (a business negotiator) to learn from him. For additional information, the UC has categorized lecturer into two: lecturer in academic field and entrepreneurs who are asked to teach in the university, or is commonly referred as entrepreneur in residence (EIR). In other words, EIR is the entrepreneurs requested by the UC to teach entrepreneurship to the students, with goal to provide business experience from the first hand to the students in order to make them have greater insight about real business practice. For example, when the students' business group plan to export their products, EIR with such expertise or who works as an exporter can assist the students in exporting process. Through this strategy, the students are provided with theoretical aspects from their academic lecturers and practical aspects from their EIR.

\section{Conclusion}

This research explores the process of implementing the entrepreneurship education process at the Ciputra University (The UC), a university with vision to produce entrepreneurs of Indonesia. By implementing student-centred learning approach, the UC educates the students in entrepreneurial way, which is creative, innovative, and willing to take measured risks. This reflects in the learning process that requires all students to start real business since their first semester.

This research has successfully examined roles of the facilitators in their students' business, especially on how to start a business and guide the business. The business initiation process is a 
very crucial one since the students change their paradigm within this process in order to become entrepreneurs. Right after that, the facilitators and the students must set the targets together in order to motivate them and to monitor their business. To guarantee that the business project goes as planned; the facilitators create performance indicators consist of two aspects: financial and nonfinancial aspects. Although they are more likely to use non-financial aspects as indicatorto measure the students' progress, both aspects are complementary and inseparable as accurate indicators. Furthermore, in the business guiding process, the most important aspect for the facilitators is to facilitate intense interaction with the students. They must really understand the way their students run their business and the way they behave and response during guidance process. Thus, without intense interaction, an effective business guiding process is impossible to achieve.

Challenges faced by the facilitators are mostly emerged from the students' aspect, such as a challenging mindset change process and different comprehension levels and skills among or within the business groups. Therefore, the facilitators must be able to manage their time well in order to teach, do research, and guide the students' project.

This research uses the facilitators' perspectives and viewpoints as informants; therefore, the future researchers in the same area of research could explore the students' perspectives or viewpoints as informants. In addition to that, it is important to explore the viewpoints of the regulator or the manager (of either department, faculty, or even university) in order to obtain more holistic results with regard to the entrepreneurship education management.

\section{References}

Alma, B. (2014). Kewirausahaan. Edisi Revisi. Bandung: Alfabeta.

Aprilianty, E. (2013). Pengaruh kepribadian wirausaha, pengetahuan kewirausahaan, dan lingkungan terhadap minat berwirausaha siswa SMK. Jurnal Pendidikan Vokasi, 2(3), 314-324

Buchari, A. (2007). Kewirausahaan, Bandung, Alfabeta

Ciputra. (2007). Pendidikan Kewirausahaan untuk Menyelesaikan Masalah Kemiskinan dan Pengangguran di Indonesia, Jakarta

Douglas, E.J., and Shepherd, D.A. (2002). Self-Employment as a Career Choice: Attitudes, Entrepreneurial Intentions, and Utility Maximization. Entrepreneurial Theory and Practice 26(3), 81-90

El-Gohary, H., Selim, H. M., \& Eid, R. (2016). Entrepreneurship Education and Employability of Arab HE Business Students: An Attempt for a Primary Investigation. International Journal of Business and Social Science, 7(4), 52-72.

Fakhruddin (2012). Kewirausahaan Masyarakat (Studi Kasus Pada Mahasiswa Jurusan Pls Universitas Negeri Semarang. Jurnal Lembaran IImu Kependidikan, 4(2), 81-88

Glass, D. W., \& Freeman, E. W. (2016). The Efficacy of a Model Rubric to Enhance Experiential Learning in an Entrepreneurship Course: A Case Research. St. Andrews University

Hakim, D. (2012). Pengembangan Pendidikan Kewirausahaan Berdasarkan Nilai-Nilai Budaya Untuk Membentuk Daya Saing Dan Karakter Bangsa, 1(2). Prosiding Seminar Nasional Competitive Advantage.

Lee, W. L. (2016). SCRUM-X: An Interactive and Experiential Learning Platform for Teaching Scrum. Conference Paper, 1-6

Lestari, R.B., Trisnady, W. (2012). Pengaruh Pendidikan Kewirausahaan Terhadap Minat Berwirausaha Mahasiswa di STIE MDP, STMIK MDP, STIE MUSI. Jurnal IImiah STIE MDP, 1(2), 112-119.

Mahfud, P. (2012). Praksis Pembelajaran Kewirausahaan pada Unit Produksi Jasa Boga. Jurnal Pendidikan Vokasi, 2(1), 27-39.

Nicholson, J., Shen, Y., \& Nicholson, D. (2016). Increasing Intrapreneurial Intentions among Business Students: Using a Net-Enabled Business Innovation Cycle (NEBIC) Theory Team Project. Journal of Higher Education Theory and Practice, 16(3), 84-93

Nurseto (2010) Pendidikan Berbasis Entrepreneur. Jurnal Pendidikan Akuntansi Indonesia, 8(2), 52 - 59

Pihie, Z. A. L., \& Sani, A. S. A. (2009). Exploring the entrepreneurial mindset of students: implication for improvement of entrepreneurial learning at university. The Journal of International Social Research, 2(8), 340-345.

Winarto, P. (2004). First Step To Be An Entrepreneur. Jakarta, Elex Media Komputindo.

Priyanto, S.H. (2009) Mengembangkan Pendidikan Kewirausahaan Di Masyarakat. Andragogia - Jurnal Pnfi, $1(1), 57-82$

Sarwoko (2011). Kajian Empiris Entrepreneur Intention Mahasiswa. Jurnal Ekonomi Bisnis, 16(2), 126-135

Siswoyo (2009) Pengembangan Jiwa Kewirausahaan Di Kalangan Dosen dan Mahasiswa. Jurnal Ekonomi Bisnis, 14(2), 114-123. 
Skinner, K. L., Hyde, S. J., McPherson, K., \& Simpson, M. D. (2016). Improving Students' Interpersonal Skills through Experiential Small Group Learning. Journal of Learning Design, 9(1), 21-36.

Stokvik, H., Adriaenssen, D. J., \& Johannessen, J. A. (2016). Strategic entrepreneurship and intrapreneurial intensity. Problems and Perspectives in Management,14(2), 348-359

Utomo (2010). Menumbuhkan Minat Kewirausahaan Sosial. Jurnal IImiah Among Makarti, 3(5), 95-104.

Wahid, A., Ibrahim, A., \& Hashim, N. B. (2017). The Review Of Teaching And Learning On Entrepreneurship Education In Institution Of Higher Learning. Journal on Technical and Vocational Education, 1(2), 82-88.

Yin, K. R. (2003). Case Study Research Design and Methods. Sage Publication 